\title{
A Comparison in Growth and Water Use Efficiency between Superior and Inferior Families from Open-Pollinated Progenies of Pinus densiflora under Different Environmental Conditions
}

\author{
Chang-Young Oh${ }^{1 *}$, Sang-Urk Han ${ }^{1}$, Byung-Whan Cheon ${ }^{2}$ and Chan-Jin $\mathrm{Oh}^{3}$ \\ ${ }^{1}$ Department of Forest Genetic Resources, Korea Forest Research Institute, Suwon 441-847, Korea \\ ${ }^{2}$ Korea Forestry Promotion Institute, Seoul 129-914, Korea \\ ${ }^{3}$ Jeollanam-do Forest Resources Research Institute, Naju 520-833, Korea \\ (Received April 5, 2013; Revised June 10, 2013; Accepted June 24, 2013)

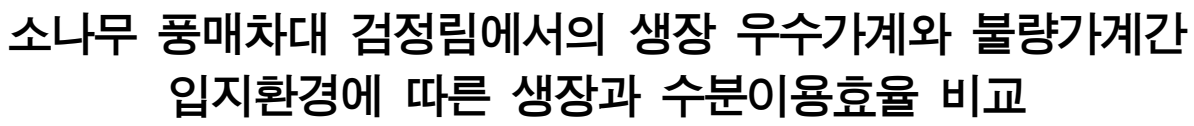 \\ 오창영 ${ }^{1 *}$ - 한상억 ${ }^{1} \cdot$ 전병환 $^{2} \cdot$ 오찬진 $^{3}$ \\ 1국립산림과학원 산림유전자원부, ${ }^{2}$ 한국임업진흥원, ${ }^{3}$ 전남산림자원연구소 \\ (2013년 4월 5일 접수; 2013년 6월 10일 수정; 2013년 6월 24일 수락)
}

\begin{abstract}
To understand the relationship of growth and water use efficiency (WUE) between superior and inferior families from open-pollinated progenies of $P$. densiflora, two families (one superior and one inferior families) in two open-pollinated progeny test sites were selected using volume growth at 26 years. And we compared environmental factors and WUE which was calculated from measured $\delta^{13} \mathrm{C}$ in the wood. The $\delta^{13} \mathrm{C}$ change during the last 20 years showed steady decrease and same pattern as WUE in the fertile site, while there was an inverse relationship between $\delta^{13} \mathrm{C}$ and WUE in poor site, indicating an interaction between gene and environment. The superior family showed higher WUE than inferior family in poor site, indicating efficient stomatal control of the former under water stress. Water use efficiency calculated by carbon isotope composition can be used as a selection criterion for drought tolerance families in openpollinated progenies of $P$. densiflora.
\end{abstract}

Key words: Pinus densiflora, Open-pollinated progenies, Drought stress, Carbon isotope composition, Water use efficiency

\section{INTRODUCTION}

Pinus densiflora Sieb. \& Zucc. is one of the most economically and culturally important species in Korea with a wide range of distribution. It has well adapted to different soil types and environmental conditions up to $1,000 \mathrm{~m}$ above sea level throughout the Korean peninsula. The natural forest of $P$. densiflora covers about
1.5 million ha of Korean forest region (Korea Forest Service, 2008). Recently, some populations of $P$. densiflora in Southern part of Korea have shown forest decline due to severe water deficit under high temperature and little precipitation in winter season. However P. densiflora has been known to have drought tolerance (or avoidance) mechanism (Lee, 2011). The drought tolerance may be partly explained by high water use 
efficiency which has shown wide variation among different species and within species.

Intercellular $\mathrm{CO}_{2}$ concentration is reduced by stomatal closure in response to drought stress (Schulze, 1986; Grant et al., 2006), and thus $\mathrm{CO}_{2}$ concentration at the site of carboxylation in the chloroplasts is also reduced (Evans and von Caemmerer, 1996; Warren, 2006). Under this water-stressed condition, ${ }^{12} \mathrm{C}$ is depleted faster than under normal condition, which results in increased partial pressure of ${ }^{13} \mathrm{C}$. Consequently, carbon isotope signature of newly formed photosynthates could be increased (Brugnoli et al., 1988; Farquhar et al., 1989), and reflects the balance between stomatal conductance and photosynthetic rate, i.e. water use efficiency, which is related to water potential (Damesin et al., 1998; Warren et al., 2001), humidity (Saurer and Siegenthaler, 1989), and precipitation (Schulze et al., 1998; Korol et al., 1999; Warren et al., 2001).

Carbon isotope composition $\left(\delta^{13} \mathrm{C}\right)$ and tree growth are often negatively or positively correlated. Some species show greater $\delta^{13} \mathrm{C}$ indicating greater water use efficiency, with the correlation being negative due to reduced growth (McNulty and Swank, 1995; Pita et al., 2001). In contrast, some conifer species show a positive correlation between growth and $\delta^{13} \mathrm{C}$ (Johnsen et al., 1999; Xu et al., 2000; Brendel et al., 2002). Reduced stomatal conductance caused by drought stress makes negative correlation (Osorio and Pereira, 1994; Pita et al., 2001), whereas changes in carboxylation efficiency makes positive correlation (Johnsen and Major, 1995; Johnsen et al., 1999; Xu et al., 2000). Genetic variation in $\delta^{13} \mathrm{C}$ is common and has been reported in many species (Zhang and Marshall, 1995; Prasolova et al., 2001). Some studies have advocated that $\delta^{13} \mathrm{C}$ can be the selection criterion for productivity under drought stress (Bond and Stock, 1990; Xu et al., 2000; Codon et al., 2004). Low interaction between genotype and environment for $\delta^{13} \mathrm{C}$ and high narrow-sense heritability for $\delta^{13} \mathrm{C}$ suggest that there is good potential for genetic gain for WUE via selections (Rajabi et al., 2008).

In Korea, the breeding program for $P$. densiflora was initiated in 1959. Plus-trees have been selected through the natural range of the species and tested by means of open-pollinated progeny tests (Oh et al., 2009). Up to now the main objective of breeding program was increase in volume growth. Our group has reported just physiological differences between superior and inferior families, but at that time we could not confirm the fac- tors causing the differences between families (Oh et al., 2008). To cope with presupposed climate change and drought stress, progeny test should be concerned with physiological responses to drought stress to improve breeding efficiency. This study was conducted to investigate the relationship of growth and water use efficiency between superior and inferior families from open-pollinated progenies of $P$. densiflora under different environmental conditions.

\section{MATERIALS AND METHODS}

\subsection{Data collection and plant materials}

Two progeny test sites for $P$. densiflora were used in this study. They were established in 1981 and located in Chuncheon city of Gangwon province and Naju city
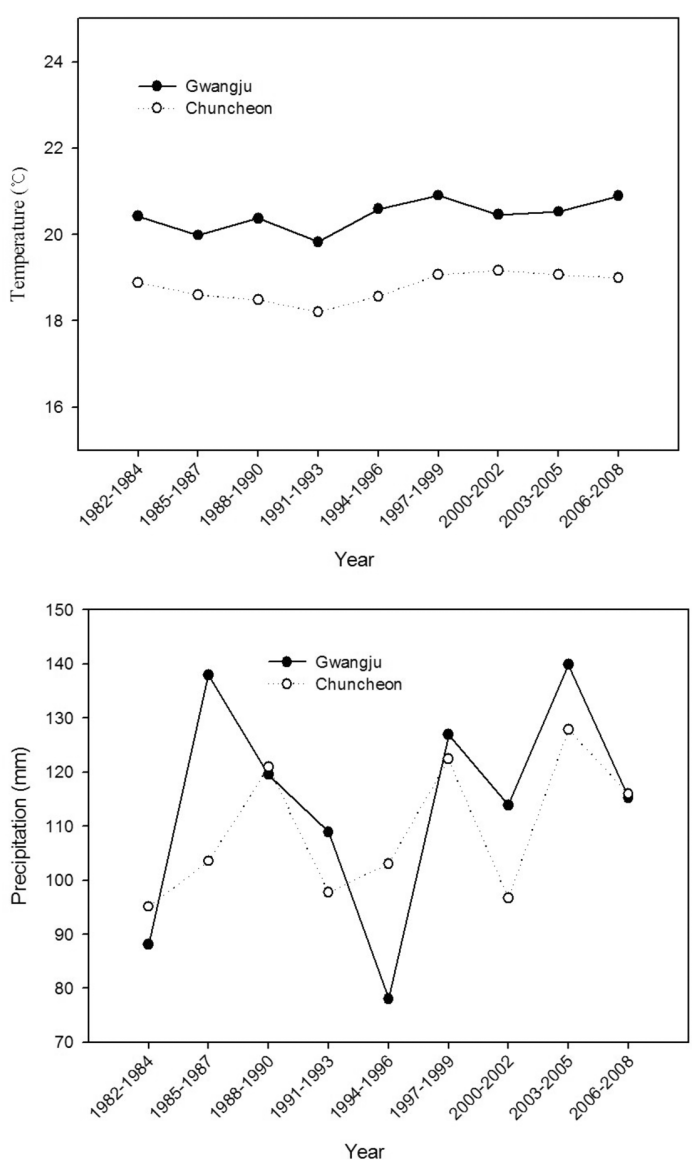

Fig. 1. Three-year term annual mean temperature (top) and three-year term monthly mean precipitation (bottom) from 1982 to 2008 at the weather station in Chuncheon and Gwangju. 
Table 1. Physical and chemical properties of soil of Chuncheon and Naju sites surveyed in 2006

\begin{tabular}{|c|c|c|c|c|c|c|c|c|c|c|}
\hline \multirow{2}{*}{ Site } & \multirow{2}{*}{ Texture } & \multirow{2}{*}{$\mathrm{pH}$} & \multirow{2}{*}{$\begin{array}{c}\text { O.M. } \\
(\%)\end{array}$} & \multirow{2}{*}{$\begin{array}{l}\text { T.N. } \\
\text { (\%) }\end{array}$} & \multirow{2}{*}{$\begin{array}{c}\text { Avail. } \mathrm{P}_{2} \mathrm{O} \\
(\mathrm{mg} / \mathrm{kg})\end{array}$} & \multirow{2}{*}{$\begin{array}{c}\text { C.E.C } \\
\left(\mathrm{cmol}^{+} / \mathrm{kg}\right)\end{array}$} & \multicolumn{4}{|c|}{ Exchangeable $\left(\mathrm{cmol}^{+} / \mathrm{kg}\right)$} \\
\hline & & & & & & & $\mathrm{K}^{+}$ & $\mathrm{Na}^{+}$ & $\mathrm{Ca}^{++}$ & $\mathrm{Mg}^{++}$ \\
\hline Chuncheon & $\mathrm{L}$ & 5.0 & 5.61 & 0.22 & 5.85 & 13.42 & 0.23 & 0.06 & 1.52 & 0.64 \\
\hline Naju & $\mathrm{L}$ & 4.6 & 2.41 & 0.09 & 0.58 & 7.65 & 0.11 & 0.09 & 0.53 & 0.36 \\
\hline
\end{tabular}

O.M.: organic matters, T.N.: total nitrogen, C.E.C.: cation exchangeable capacity

This data table was modified from the original data of Han et al. (2006).

of Jeonnam province. Temperature and precipitation data were collected from the nearest weather station records for each site; Chuncheon Weather Station for Chuncheon, and Gwangju Weather Station for Naju. The data of three-year average annual temperature and monthly precipitation (Fig. 1) were calculated and soil data by Han et al. (2007) were used (Table 1).

Among the 232 open-pollinated progenies two extreme families were selected based on growth performance at 26 years. The CB2 representing superior family ranked number one, while the KW19 representing inferior family ranked number 212 among 232 progenies based on genetic combining ability (Oh et al., 2009). In November 2007, three individuals from each progeny were selected and sampled for stem disks at $0.2 \mathrm{~m}, 1.2 \mathrm{~m}$ height from the ground and every $2 \mathrm{~m}$ from 1.2 height. Ring width was measured to a precision of $0.01 \mathrm{~mm}$ and the wood samples for 3-year bands during the 19822008 period. We used computer program (SNASYS, ver. 2.0) to calculate the annual volume increment.

\subsection{Analytical procedures}

After measuring the ring width, the disks taken 1.2 meter in height were selected to collect a series of 3year bands from newly formed secondary xylem and grounded to powder for carbon isotope ratio analyses. Carbon isotope ratios were determined using a continuous-flow stable isotope ratio mass spectrometer (IsoPrime-EA, Micromass, UK). Carbon isotope composition was calculated by:

$$
\delta(\% \text { o })=\left[\left(\mathrm{R}_{\text {sample }} / \mathrm{R}_{\text {standard }}\right)-1\right] \times 1000
$$

where, $\mathrm{R}$ is the ratio of ${ }^{13} \mathrm{C} /{ }^{12} \mathrm{C}$, and the standard was the Pee Dee Belemnite (PDB).

The intrinsic water-use efficiency (WUE) quantifies the amount of carbon assimilated per unit leaf area per unit time at per unit cost of water. This is defined by the ratio of $\mathrm{CO}_{2}$ assimilation rate (A) to stomatal conductance for water vapor $\left(\mathrm{g}_{\mathrm{w}}\right)$ (Korol et al., 1999; Saurer et al., 2004).

$$
\mathrm{A} / \mathrm{g}_{\mathrm{w}}=\left(\mathrm{C}_{\mathrm{a}}-\mathrm{C}_{\mathrm{i}}\right) / 1.6
$$

where, $\mathrm{C}_{\mathrm{a}}$ and $\mathrm{C}_{\mathrm{i}}$ are the $\mathrm{CO}_{2}$ concentration in the atmosphere and the leaf intercellular space, respectively. The $\mathrm{C}_{\mathrm{i}}$ can be calculated from wood $\delta^{13} \mathrm{C}$ $\left(\delta^{13} \mathrm{C}_{\mathrm{w}}\right)$, atmospheric $\delta^{13} \mathrm{C}\left(\delta^{13} \mathrm{C}_{\mathrm{a}}\right)$ and $\mathrm{C}_{\mathrm{a}}$ by using eq. (3) (Farquhar et al., 1982; Farquhar et al., 1989; Korol et al., 1999).

$$
\mathrm{C}_{\mathrm{i}}=\left(\delta^{13} \mathrm{C}_{\mathrm{a}}-\delta^{13} \mathrm{C}_{\mathrm{w}}-4.4 \% \mathrm{o}\right) \times \mathrm{C}_{\mathrm{a}} / 22.6 \%
$$

The $\delta^{13} \mathrm{C}_{\mathrm{a}}$ and $\mathrm{C}_{\mathrm{a}}$ are obtained from the regression curves by Feng (1998).

$$
\begin{aligned}
& \delta^{13} C_{a}=-6.429-0.006 \exp [0.0217(t-1740)] \\
& C_{a}=277-78+1.35 \exp [0.01572(t-1740)]
\end{aligned}
$$

where, $\mathrm{t}$ is time in years and middle year of each collected 3-year bands were used.

To statistical analysis, the t-test was used to compare differences between families in each site.

\section{RESULTS AND DISCUSSION}

\subsection{Annual volume increment}

Fig. 2 shows annual volume increment in the two families in two sites. The superior family, CB2, showed higher volume increment than the inferior family, KW19, in both sites. The growth curve showed a sigmoid shape typical of young pine stands. Statistically significant difference in increment between the two families was initiated in the year of 2000 in Chuncheon site, but in Naju site it was initiated in the year of 1985 .

As shown in Table 1, soil of Chuncheon site showed better physical and chemical properties than Naju site for tree growth. According to the results of Han et al. (2007) there were higher values of organic matters, total nitrogen, and available phosphorus in Chuncheon site than in Naju site. These differences in soil fertility between the two sites may explain the growth difference between the two sites and first recognition period of significant growth differences. Within each site 

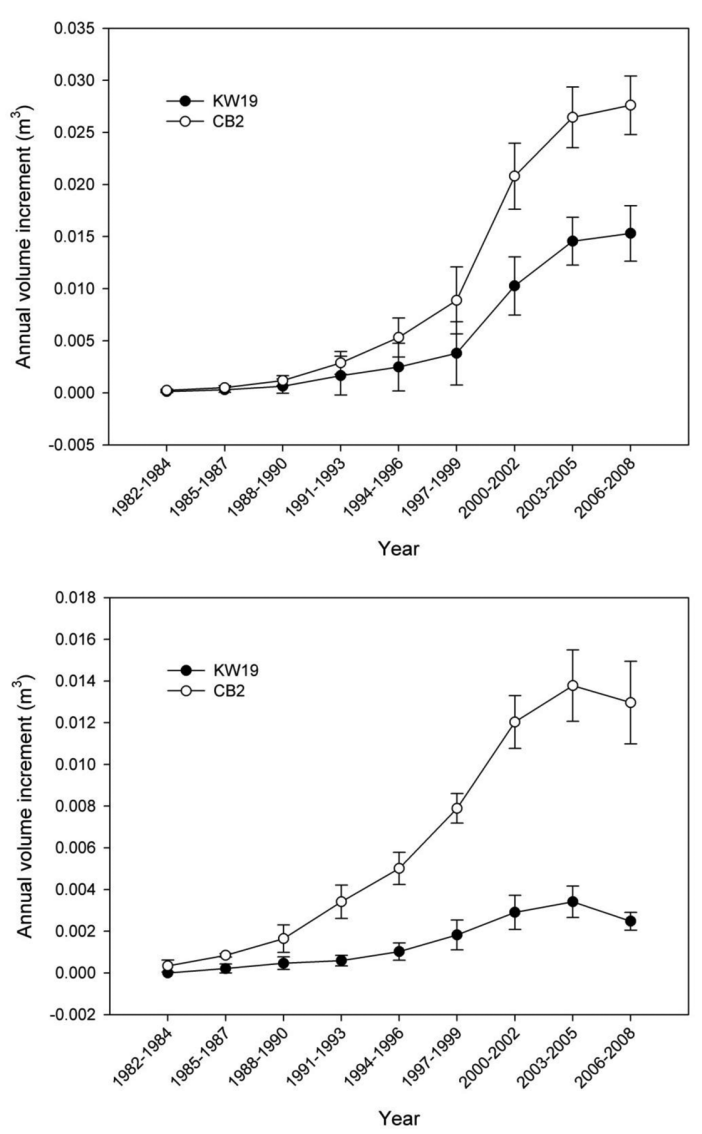

Fig. 2. Annual volume increment of each half-sib progenies of CB2 and KW19 in Chuncheon (top) and Naju (bottom) progeny test sites.

superior family (CB2) grew better than inferior family (KW19) indicating the differences of genetic origin.

As shown in Fig. 1, the three-year term annual mean temperature of Chuncheon and Naju sites represented about 19 and $21^{\circ} \mathrm{C}$, respectively. On the other hand, three-year term monthly mean precipitation fluctuated during the observation period of 26 years. There were severe drought periods in the early 1980s and in the middle of 1990s especially in Naju site. Therefore, these drought conditions may distinguish the growth potential differences between families in each site.

\subsection{Carbon isotope composition and water use efficiency}

Fig. 3 shows changes in the carbon isotope composition during the last 20 years (1988-2008). There was a continuously decreasing $\delta^{13} \mathrm{C}$ pattern over time in Chuncheon site. This pattern may be primarily related
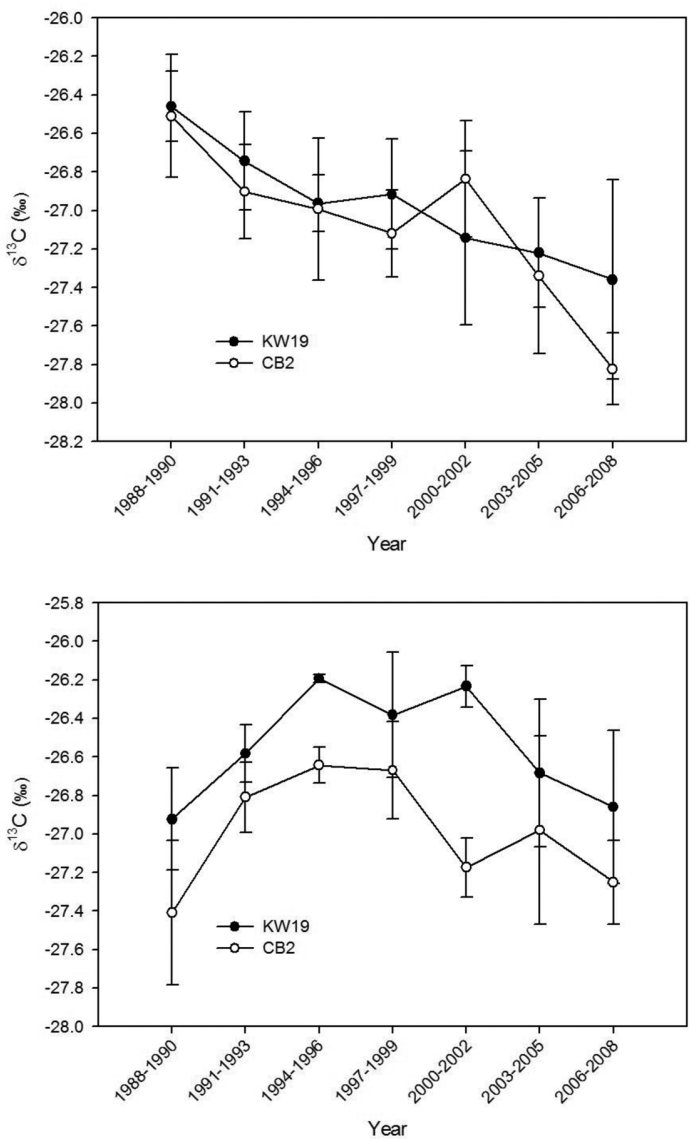

Fig. 3. Changes in $\delta^{13} \mathrm{C}$ between 1988 and 2008 in 3-year tree ring bands of each progenies in Chuncheon (top) and Naju (Bottom).

to the increased emission of anthropogenic $\mathrm{CO}_{2}$ which has relatively depleted ${ }^{13} \mathrm{C}$ in the atmosphere by green plants (Bert et al., 1997; February and Stock, 1999). On the other hand Naju site showed an increasing trend up to the middle of 1990s and a decreasing pattern thereafter.

The differences in environmental conditions between Chuncheon and Naju sites were both soil conditions and climatic factors. Korol et al.(1999) reported that soil fertility did not affect any variations in $\delta^{13} \mathrm{C}$, while carbon isotope composition is subject to change with level of water stress. Thus the variation of $\delta^{13} \mathrm{C}$ in Naju site was caused by varying precipitation. In Naju site there was merely less than $80 \mathrm{~mm}$ monthly precipitation during 1994-1996, which was almost half of other periods (Fig. 1). Therefore tree growth could be affected by severe drought stress in that period in Naju. As 
Table 2. Statistical significances of difference in $\delta^{13} \mathrm{C}$ between families in each sites

\begin{tabular}{cccccccc}
\hline \hline Site & $1988-1990$ & $1991-1993$ & $1994-1996$ & $1997-1999$ & $2000 \sim 2002$ & $2003 \sim 2005$ & $2006 \sim 2008$ \\
\hline Chuncheon & n.s. & n.s. & n.s. & n.s. & n.s. & n.s. & n.s. \\
Naju & n.s. & n.s. & $*$ & n.s. & $* *$ & n.s. & n.s. \\
\hline
\end{tabular}

${ }^{*} \mathrm{p} \leq 0.05,{ }^{* *} \mathrm{p} \leq 0.01$, and $\mathrm{n} . \mathrm{s} .:$ non-significance
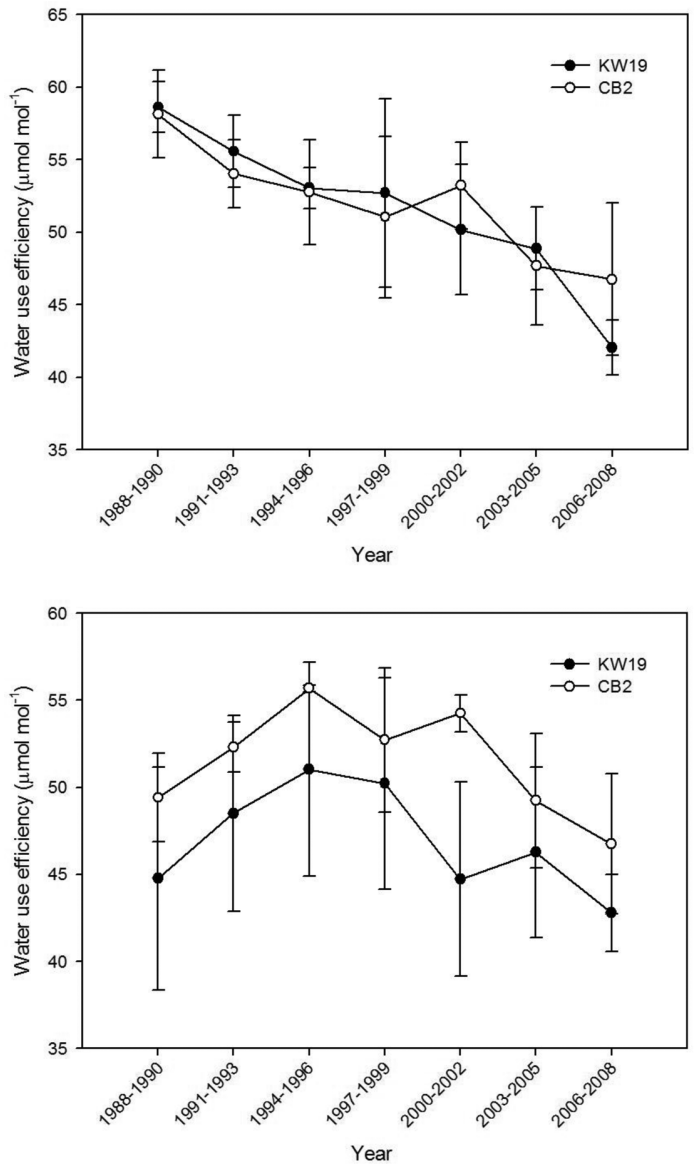

Fig. 4. Changes in water-use efficiency between 1988 and 2008 of each progenies in Chuncheon (top) and Naju (bottom).

shown in Fig. 3 and Table 2, the inferior family (KW19) showed higher $\delta^{13} \mathrm{C}$ in the Naju site under the unfavorable weather condition, such as higher air tem- perature combined with low precipitation, in the middle of 1990s.

Fig. 4 shows water use efficiency (WUE) of superior and inferior families in the two sites. As shown in Table 3, in Chucheon site there was no difference in WUE between the two families. On the other hand the superior CB2 in Naju site showed higher WUE value than that of inferior KW19 during 1994-1996 and 2000 2002, which was an opposite trend compared with lower carbon isotope composition of CB2 in Fig. 3. The pattern of the variation in WUE showed the same pattern as the variation of $\delta^{13} \mathrm{C}$ as reported earlier (Farquhar et al., 1989: Meinzer et al., 1990). Thus in this study $P$. densiflora improved water-use efficiency by control of stomatal conductance under drought stress, which was similar to the result of Yordanov et al. (2000).

Even though precipitation in Chuncheon site with high soil fertility during the two periods of 1991-1993 and 2000-2002 was much lower than other periods, there was no difference in WUE and $\delta^{13} \mathrm{C}$ between the two families. It suggested that soil fertility might influence differential response of the two families to $\delta^{13} \mathrm{C}$ and WUE. This is supported by Kleiner et al.(1992) who reported that drought tolerance was generally increased by increased soil fertility. This study indicates that we cannot select drought tolerant individuals based on WUE and $\delta^{13} \mathrm{C}$ under high soil fertility environment.

P. densiflora is a pioneer species with low nutrient requirement. Thus it can endure such unfavorable soil conditions. The result of this study showed that the superior family in growth showed low $\delta^{13} \mathrm{C}$ and high WUE in unfavorable conditions. Consequently knowledge on carbon isotope composition could be applied

Table 3. Statistical significances of difference in WUE between families in each sites

\begin{tabular}{cccccccc}
\hline \hline Site & $1988-1990$ & $1991-1993$ & $1994-1996$ & $1997-1999$ & $2000 \sim 2002$ & $2003 \sim 2005$ & $2006 \sim 2008$ \\
\hline Chuncheon & n.s. & n.s. & n.s. & n.s. & n.s. & n.s. & n.s. \\
Naju & n.s. & n.s. & $*$ & n.s. & $* *$ & n.s. & n.s. \\
\hline
\end{tabular}


to selection of drought tolerance cultivars for afforestation on burned sites by forest fire. And also it could be applied to cope with global warming which brings in weak adaptation of pines to winter desiccation with low rainfall. Pines are introduced to burned sites where soil is usually dry due to lack of an organic layer and hydrophobic nature of burned soil and where high water use efficiency is directly related to successful afforestation as suggested by Archibald(1995). For this purpose we could select drought tolerant individuals such as the superior family in our study that has high water use efficiency under poor soil condition and high level of water stress

\section{IV. 적 요}

본 연구는 소나무 풍매차대를 대상으로 환경이 다른 두 지역에서 토양 양료 수준, 강수량 등을 조사하여 이를 생장, 수분이용효율과 비교함으로써 현지에서 건 조스트레스를 받았는지 확인하고, 건조스트레스에 의한 반응에서 수분이용효율이 유전적으로 구분되는지 구명 하고자 하였다. 소나무 풍매차대 26년생의 재적생장을 이용하여 생장 우수가계와 불량가계를 구분하였다. 수 분이용효율은 건조기에는 증가하는 것으로 나타났다. 지난 20년간 토양 양료 조건이 좋은 곳에서는 탄소안 정성동위원소 함량비는 서서히 감소하는 경향이었으며, 수분이용효율 역시 비슷한 경향으로 나타났다. 하지만 토양 양료 조건이 좋지 않은 곳에서는 유전적 요인과 환경적 요인의 상호작용으로 탄소안정성동위원소 함량 비와 수분이용효율은 반대의 경향으로 나타났다. 생장 우수가계는 수분 스트레스를 받는 상황에서 기공을 효 과적으로 조절하여 불량가계에 비하여 토양이 불량한 지역에서 높은 수분이용효율을 나타냈다. 결론적으로 탄소안정성동위원소 함량비를 이용한 수분이용효율은 소나무 풍매차대를 대상으로 건조스트레스에 대한 선 발 기준으로 이용할 수 있다.

\section{REFERENCES}

Archibald, O. W., 1995: Mediterranean ecosystems. Ecology of World Vegetation. O. W. Archibald (Eds.), Chapman \& Hall, 131-164.

Bert, D., S. W. Leavitt, and J. L. Dupouey, 1997: Variations of wood $\delta^{13} \mathrm{C}$ and water-use efficiency of Abies alba during the last century. Ecology 78, 1588-1596.

Bond, W. J., and W. D. Stock, 1990: Preliminary assessment of the grading of Eucalyptus clones using carbon isotope discrimination. Southern African Forestry Jour- nal 154, 51-54.

Brendel, O., D. Pot, C. Plomion, P. Rozenberg, and J. M. Guehl, 2002: Genetic parameters and QTL analysis of $\delta^{13} \mathrm{C}$ and ring width in maritime pine. Plant, Cell and Environment 25, 945-953.

Brugnoli, E., K. T. Hubick, S. von Caemmerer, S. C. Wong, and G. D. Farquhar, 1988: Correlation between the carbon isotope discrimination in leaf starch and sugars of C3 plants and the ratio of intercellular and atmospheric partial pressures of carbon dioxide. Plant Physiology 88, 1418-1424.

Codon, A. G., R. A. Richards, G. J. Tebetzke, and G. D. Farquhar, 2004: Breeding for high water-use efficiency. Journal of Experimental Botany 55, 2447-2460

Damesin, C., S. Rambal, and R. Joffre, 1998: Co-occurrence of trees with different leaf habit: a functional approach on Mediterranean oaks. Acta Oecologia. 19, 195-204.

Evans, J. R., and S. von Caemmerer, 1996: Carbon dioxide diffusion inside leaves. Plant Physiology 110, 339346.

Farquhar, G. D., J. R. Ehleringer, and K. T. Hubick, 1989: Carbon isotope discrimination and photosynthesis. Annual Review of Plant Physiology 40, 503-537.

Farquhar, G. D., M. H. O'Leary, and J. A. Berry, 1982: On the relationship between carbon isotope discrimination and intercellular carbon dioxide concentration in leaves. Australian Journal of Plant Physiology 9, 121-137.

February, E. C., and W. D. Stock, 1999: Declining trend in the ${ }^{13} \mathrm{C} /{ }^{12} \mathrm{C}$ ratio of atmospheric carbon dioxide from tree rings of Soouth African Widdringtonia cedarbergensis. Quaternary Research 52, 229-236.

Feng, X., 1998: Long-term ci/ca response of trees in western North America to atmospheric $\mathrm{CO}_{2}$ concentration derived from carbon isotope chronologies. Oecologia 117, 1925.

Grant O. M., M. M. Chaves, and H. G. Jones, 2006: Optimizing thermal imaging as a technique for detecting stomatal closure induced by drought stress under greenhouse conditions. Physiologia Plantarum 27, 507-518.

Han, S. U., C. Y. Oh, C. S. Kim, Y. J. Kim, K. N. Kang, and S. M. Lee, 2007: Time trends for genetic parameters of growth traits in open-pollinated progenies of Pinus densiflora. Korean Journal of Breeding Society 39, 457-463. (in Korean with English abstract)

Johnsen, K. H., L. B. Flanagan, D. A. Huber, and J. E. Major, 1999: Genetic variation in growth, carbon isotope discrimination, and foliar $\mathrm{N}$ concentration in Picea mariana: analyses from a half diallel mating design using field grown trees. Canadian Journal of Forest Research 29, 1727-1735.

Johnsen, K. H., and J. E. Major, 1995: Gas exchange of 20-year-old black spruce families displaying a genotype $\times$ environment interaction in growth rate. Canadian 
Journal of Forest Research 25, 430-439.

Kleiner, K. W., M. D. Abrams, and J. C. Schultz, 1992: The impact of water and nutrient deficiencies on the growth, gas exchange and water relations of red oak and chestnut oak. Tree Physiology 11, 271-278.

Korea Forest Service, 2008: Statistical Year Book of Forestry.

Korol, R. L., M. U. F. Kirschbaum, G. D. Farquhar, and M. Jeffreys, 1999: Effects of water status and soil fertility on the C-isotope signature in Pinus radiata. Tree Physiology 19, 551-562.

Lee, K. J., 2011: Tree Physiology (3rd ed.). Seoul National University Press, 536pp

McNulty, S. G., and W. T. Swank, 1995: Wood $\delta^{13} \mathrm{C}$ as a measure of annual basal area growth and soil water stress in a Pinus strobus forest. Ecology 76, 1581-1586.

Meinzer, F. C., G. Goldstein, and D. A. Grantz, 1990: Carbon isotope discrimination in coffee genotypes grown under limited water supply. Plant Physiology 92, 130135.

Oh, C. Y., S. U. Han, and C. S. Kim, 2008: Differences of physiological responses according to growing conditions between superior family and inferior family in Pinus densiflora. Korean Journal of Breeding Society 40, 136-142. (in Korean with English abstract)

Oh, C. Y., S. U. Han, K. J. Lee, C. S. Kim, C. J. Oh, and D. H. Ji, 2009: Family selection on height growth in open-pollinated progeny trials of Pinus densiflora using relative height growth rate. Korean Journal of Breeding Society 41, 220-227. (in Korean with English abstract)

Osorio, J., and J. S. Pereira, 1994: Genotypic differences in water use efficiency and ${ }^{13} \mathrm{C}$ discrimination in Eucalyptus globulus. Tree Physiology 14, 871-882.

Pita, P., F. Soria, I. Canas, G. Toval, and J. A. Pardos, 2001: Carbon isotope discrimination and its relationship to drought under field conditions in genotypes of Eucalyptus globules Labill. Forest Ecology and Management 141, 211-221.

Prasolova, N. V., Z. H. Xu, G. D. Farquhar, P. G. Saffigna, and M. J. Dieters, 2001: Canopy carbon and oxygen isotope composition of 9-year-old hoop pine families in relation to seedling carbon isotope composition, growth, field growth performance, and canopy nitrogen concen- tration. Canadian Journal of Forest Research 31, 673681.

Rajabi, A., H. Griffiths, E. S. Ober, W. Kromdijk, and J. D. Pidgeon, 2008: Genetic characteristics of water-use related traits in sugar beet. Euphytica 160, 175-187.

Saurer, M., and U. Siegenthaler, 1989: ${ }^{13} \mathrm{C} /{ }^{12} \mathrm{C}$ isotope ratios in trees are sensitive to relative humidity. Dendrochronologia 7, 9-13.

Saurer, M., R. T. W. Siegwolf, and F. H. Schweingruber, 2004: Carbon isotope discrimination indicates improving water-use efficiency of trees in northern Eurasia over the last 100 years. Global Change Biology 10, 21092120 .

Schulze, E. D., 1986: Carbon dioxide and water vapor exchange in response to drought in the atmosphere and in the soil. Annual Review of Plant Physiology and Plant Molecular Biology 37, 247-274.

Schulze, E. D., R. J. Williams, G. D. Farquhar, W. Schulze, J. Langridge, J. M. Miller, and B. H. Walker, 1998: Carbon nitrogen isotope discrimination and nitrogen nutrition of trees along a rainfall gradient in northern Australia. Australian Journal of Plant Physiology 25, 413-425.

Warren, C. R., 2006: Estimating the internal conductance to $\mathrm{CO}_{2}$ movement. Functional Plant Biology 33, 431442.

Warren, C. R., J. F. McGrath, and M. A. Adams, 2001: Water availability and carbon isotope discrimination in conifers. Oecologia 127, 476-486.

Xu, Z. H., P. G. Saffigna, G. D. Farquhar, J. A. Simpson, R. J. Haines, S. Walker, D. O. Osborne, and D. Guinto, 2000: Carbon isotope discrimination and oxygen isotope composition in clones of the F1 hybrid between slash pine and Caribbean pine in relation to tree growth, water use efficiency and foliar nutrient concentration. Tree Physiology 20, 1209-1217.

Yordanov, I., V. Velikova, and T. Tsonev, 2000: Plant responses to drought, acclimation, and stress tolerance. Photosynthetica 38, 171-186.

Zhang, J. W., and J. D. Marshall, 1995: Variation in carbon isotope discrimination and photosynthetic gas exchange among populations of Pseudotsuga menziesii and Pinus ponderosa in different environment. Functional Ecology 9, 402-412. 